\title{
Length-weight, maturity, and condition factor of torpedo scads (Megalaspis cordyla Linnaeus, 1758) in the Java Sea, Indonesia
}

\author{
DIAN OKTAVIANI ${ }^{1, \boldsymbol{v}}$, EKO PRIANTO $^{2}$, DUTO NUGROHO ${ }^{1}$ \\ ${ }^{1}$ Research Centre for Fisheries, Agency for Research and Human Resource of Marine and Fisheries. BRSDM KP II Building. J1. Pasir Putih II, Ancol \\ Timur, Jakarta 14430, Indonesia. Tel.: +62-21-64700928, Fax.: 62-21-64700929, `email: dianoktavianni@gmail.com \\ ${ }^{2}$ Faculty of Fisheries and Marine Science, Universitas Riau. J1. H.R. Subrantas Km 12.5, Kampus Bina Widya, Simpang Baru, Panam, Pekanbaru 28263, \\ Riau, Indonesia
}

Manuscript received: 6 November 2019. Revision accepted: 21 March 2020.

\begin{abstract}
Oktaviani D, Priyanto E, Nugroho D. 2020. Length-weight, maturity, and condition factor of torpedo scads (Megalaspis cordyla Linnaeus, 1758) in the Java Sea, Indonesia. Biodiversitas 21: 1527-1534. The Java Sea comprises the most extensive ecosystem with high pressure on the biodiversity of marine fish species in Indonesia. Small pelagic fish is the main target among marine fish species in this area for decades to fulfill the need for animal protein for human consumption. Torpedo scads (Megalaspis cordyla Linnaeus, 1758) locally called as tetengkek is one of the common species caught in small pelagic seiners fisheries in the area. The significant increasing trend of annual fish landing could lead to unsustainable long-term harvesting. This study was performed to support baseline information on the biological characteristics of Torpedo scads. Measurements on length, weight, sex, maturity, and gonad weight are the main database that collected from February to December 2017 in the Tegal fishing port, north coast of central Java. A total of 2139 specimens were available for monthly length-frequency measurements, and 601 specimens among them specifically observed for length-weight, sex, maturity stage, and their gonad weight. The result showed that fish caught within a range of 16.0-35.4 $\mathrm{cmFL}$ and weight of 40-570 g. The length-weight relationship tends to be isometric with the equation of $\mathrm{L}=7 . \mathrm{e}-03 \mathrm{~W}^{3.1511}$. The male and female ratio at 1.07: 1.0 with most of the fish caught at an immature stage (77\% of males and 63\% of females). Average Fulton condition factor $\left(K_{n}\right)$ of $1.15 \pm 0.09(0.86-1.64)$. A wide range of GSI indicates that torpedo scads partially spawn at each month of the year.
\end{abstract}

Keywords: Biological aspects, Java Sea, Megalaspis cordyla, torpedo scads

\section{INTRODUCTION}

Torpedo scads (Megalaspis cordyla) is one of the Carangidae fish family that commonly caught by the small pelagic fishery in the Java Sea. The species locally called as Tetengkek. The species broadly distributed in the pelagic ecosystem of the continental shelf, particularly in tropical and sub-tropical waters. This species biogeographically spread throughout the western Indian Ocean from East Africa, South, and Southeast Asia, Western Pacific from Japan to the northern part of Australia and eastward to Fiji Islands (Carpenter and Niem 1999). The Java Sea is one of the most abundant marine fish diversities in Indonesian waters. There are more than 20 species belong to small pelagic fish groups that were identified in seiner fishery landing (Widodo and Burhanuddin 1995). Torpedo scad is one of the small pelagic species that continuously harvested for decades. Nurdin (2007) described this species contributing to around $2 \%$ of the small scale seiners on the north coast of Java, while the heavy exploitation status occurred (Anas et al. 2011). Historical national capture fisheries statistics from 1977 to 2016 showed that landing of Megalaspis cordyla in the Java Sea significantly increased from 39 tons in 1977 to 9117 tons in 2014 then slightly decreased into 5500 tons in 2016 (DGCF, 2017). Landing mainly from seiners fishery operated in offshore waters of the north coast of the Java Sea. This phenomenon indicates that human pressures through fishing are significantly increased and directly impact to high rates of fishing mortality. Long-term high rates of fishing mortality tend to drive overfishing, and it should be avoided by managing the fish stocks within a biologically sustainable level. The trend of this fish landing is proportional to a large extent of harvesting rates to support domestic food fish supply.

Small pelagic fishery plays a significant role in coastal community livelihood on the north coast of Java. This fishery already exists for more than five decades. Observation of life-history parameters was carried out to understand the biological sensitivity of the species. Several biometric studies of small pelagic species have been conducted in the Java Sea. However, very few biological studies on this torpedo scads. The objective of this study is to provide baseline information on life-history parameters of this torpedo scad, such as the length structure, lengthweight relationship, sex-ratios, monthly variability of Fulton's condition factor, and gonado-somatic index. The study was carried out through data collection from February to December 2017 on the landing of commercial seiners in the Tegal fishing port, north coast of central Java.

Nevertheless, several biological observations of this species conducted elsewhere, such as in South Asian coastal waters of India (Sajina et al. . 2011; Jadhav and Mohite 2014), Pakistan (Qamar and Panhwar 2018; Razzaq et al. . 2019), Malaysia (Das et al. . 2014) were used as comparative information of this study. This result is 
expected to enhance the necessary information on the demographic structure of small pelagic fish in the area. Gaining an understanding of the demographic aspects of this species would assist in avoiding over-harvesting and implementing management practices for the sustainable use of the small pelagic fish resource in the Java Sea.

\section{MATERIALS AND METHODS}

\section{Study area}

The Java Sea (Figure 1), located in central-western Indonesian seas, is one of the significant contributions of small pelagic fisheries in Indonesia. Fish landed by small pelagic seiners as the main fishing gears based on the north coast of Java. Observations were made on regular monthly bases. Tegal fishing port is the site which geographically located in (6 $\left.6^{\circ} 50^{\prime} 58.01^{\prime \prime} \mathrm{S}, 109^{\circ} 7^{\prime} 43.74^{\prime \prime} \mathrm{E}\right)$ western part of the north coast of Central Java, Indonesia.

\section{Data collecting}

Demographic data of this species were obtained from direct observation and supported by a well-trained enumerator in the landing place. The specimen of different size groups collected through monthly based observation from February to December 2017.Some 2132 individuals of torpedo scads measured for length frequency. Among them, 610 specimens observed for sex determination and maturity stages. Length frequency measurements were made by measuring board from the tip of the mouth to the nearest centimeter of its caudal fin (fork length, FL). The analytical balance with a precision of $1 \mathrm{~g}$ was used to observe body weight (W) and $0.01 \mathrm{~g}$ for gonad weight $(\mathrm{Wg})$. Missing data in January due to heavy rainy season with strong wind caused limited seiners to operate in the area.

\section{Data analysis}

Length frequency distributions were measured within $0.5 \mathrm{~cm}$ intervals. The length intervals were grouped following general equation of:

$$
\mathrm{F}_{\mathrm{i}}=\left(\mathrm{n}_{\mathrm{i}} / \mathrm{N}\right) * 100
$$

\section{Where:}

$\mathrm{Fi}=$ frequency for a given interval of $0.5 \mathrm{~cm}$

ni $=$ number of specimens within intervals

$\mathrm{N}=$ total number of measured specimens

\section{Length-weight and Fulton's condition factor}

The length-weight relationship compared between males and females (smallest to largest size). The relationship of weight length will produce two constants consisting of the constant "a" is the coefficient for the weight for fish length and " $b$ " is a fish body shape parameter that follows the general equation (King, 2007) as follows:

$\mathrm{W}=\mathrm{aL}^{\mathrm{b}}$

Where: $\mathrm{W}=$ body weight $(\mathrm{g}) ; \mathrm{L}=$ length $(\mathrm{cm} \mathrm{FL})$

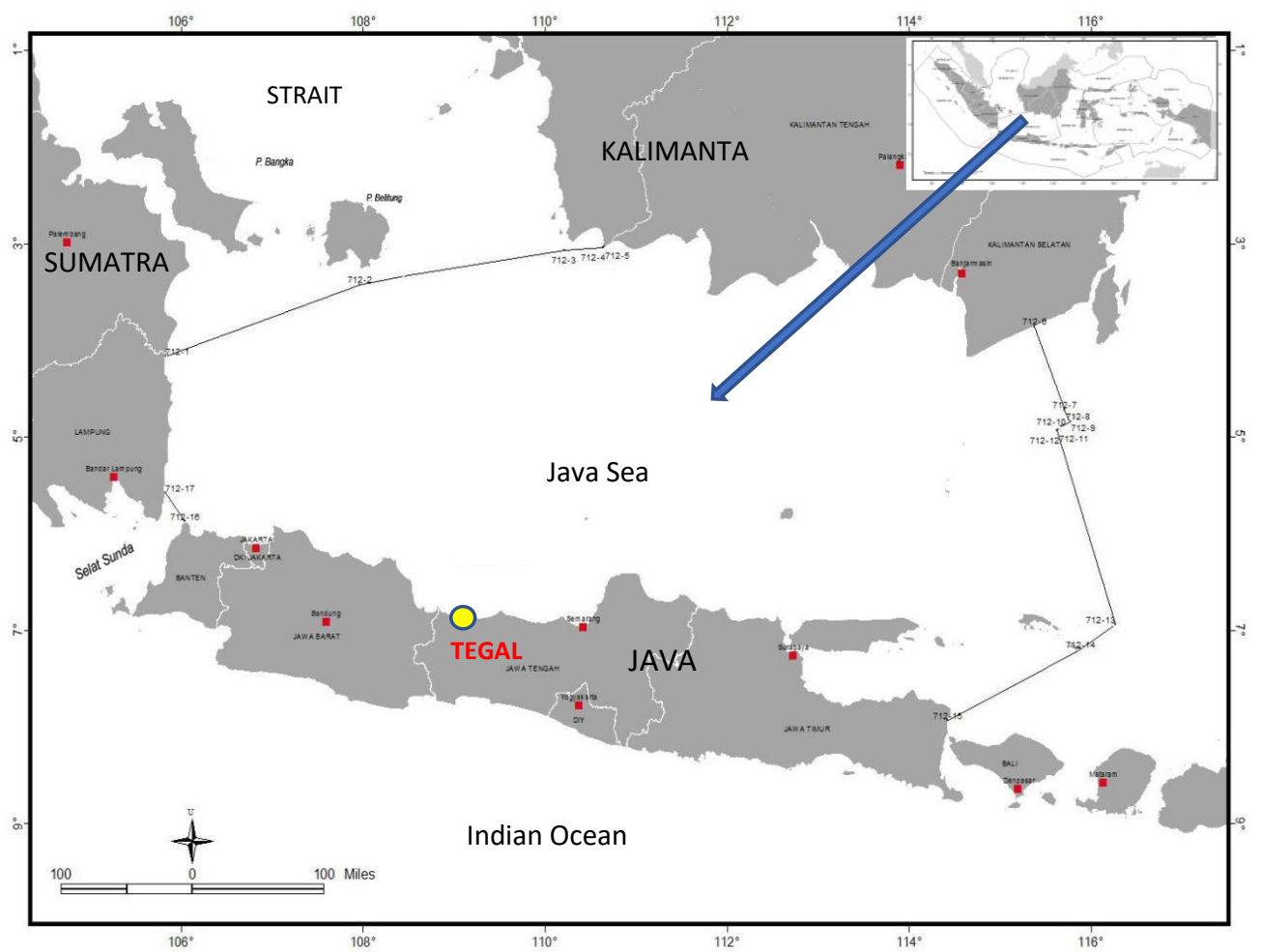

Figure 1. Tegal, north coast of Central Java, Indonesia (650'58.01" S-109 $7^{\circ} 43.74^{\prime \prime}$ E). 
In equation (2), the parameters "a" and "b" are constants based on the measured length-weight relationship. The measurement of model fit evaluated by coefficient determination ( $\mathrm{r} 2)$. The Student's t-test was used to examine the difference value of $b$. The growth would be isometric $(b=3)$, positive allometric $(b>3)$, or negative $(b<3)$. It is also applied to test the significant differences between males and females. Fulton's condition factor $(\mathrm{Kn})$ is an indicator of the health condition of individual fish, and this illustrates the mechanism of reproduction and survival (Stevenson and Woods 2006). This factor is also used to describe conditions fish at one time in a relatively similar location (Nash et al. . 2006). The index is the ratio of fish weight to length following equation Fulton (1904) in Froese (2006) as follows:

$$
\begin{aligned}
& \mathrm{Kn}=\mathrm{W} / \mathrm{L}^{3} * 100 \ldots \ldots \ldots \ldots \ldots \ldots \ldots \\
& \text { Where: } \\
& \mathrm{Kn} \quad: \text { Fulton's condition factor } \\
& \mathrm{W} \quad: \text { weight }(\mathrm{g}) \\
& \mathrm{L} \quad \text { length }(\mathrm{cm})
\end{aligned}
$$

\section{Sex ratio, maturity stages, and gonadosomatic index}

Conventional macroscopic methods applied to determine the maturation stage or spawning characteristics of torpedo scads. Different visual color levels and percent of abdominal cavity occupied by gonads were used to identify their stage of maturity. Five stages of maturity, i.e. (I) Immature, (II) Developing/Recovery, (III) Ripe, (IV) Spawning, (V) Spent (King 2007), were used in this study (Table 1).

To determine the equal proportion between sex in the wild population, the ratio of males to females performed through a Chi-square test $\left(\chi^{2}\right)$. The null hypothesis was: Ho $=$ Male : Female is $1: 1, \mathrm{H}_{1}=$ Male $:$ Female is $\neq 1: 1$.

Gonadosomatic index (GSI) as an alternative way to describe the proportion of mature fish at age or length in assessing population reproductive potential. GSI indicates gradually distinct development of gonad development and sexual maturity stages of fish. The index was computed as the ratio between gonad weight $(\mathrm{Wg})$ and body weight $(\mathrm{W})$ in each sample (Flores et al. . 2014) using the equation of:

$$
\text { GSI }=\frac{\text { Weight of gonad }}{\text { Weight of fish }} * 100
$$

\section{RESULTS AND DISCUSSION}

\section{Length frequency distribution}

A total of 2132 measured specimens were recorded during this study. Size structure ranged from 14.0 to 35.0 $\mathrm{cm}$. Most of the catch (54\%) within a range of $26-29 \mathrm{~cm}$. The population structure of torpedo scads is represented by monthly length distribution (Figure 2). The structure indicates that during March-June showed that fish caught in relatively consisted of two cohorts 15-20 cmFL and 25-30 cmFL while in July-August consisted of one cohort 25-30 $\mathrm{cm}$ FL. These may indicate that recruitment occurs from early March to June, then the number of recruitment groups is less than the adult and dominate the population structure. The recruit and adult groups exist in the same area, naturally. The vulnerable age represented by the size group of $15 \mathrm{cmFL}$ relatively not part of the fishery. Adopting the common length of $45 \mathrm{cmTL}$ or at about $40 \mathrm{cmFL}$ landed in this typical tropical fishery (Froese and Pauly 2009), the absence of this large size was uncertain whether untapped by the existing fisheries or low abundance in the sea.

Another study carried out in Ratnagiri coast Maharashtra India showed the rage of landed of this species ranged from 15.2 to $40.2 \mathrm{~cm}$ TL (Jadhav and Mohite 2014), Qamar and Panhwar (2019) observed the size ranged from 18.0-47 cm TL in coastal water of Pakistan. The maximum size reported at $80 \mathrm{~cm}$ TL and commonly attains 30 to $40 \mathrm{~cm}$ (Carpenter and Niem 1999). Compared to the size caught by seiners in India and Bangladesh waters, most of the catch in Java sea belongs to the typical size in the tropical waters seiners fisheries.

\section{Length-weight relationship, sex ratio, and Fulton's condition factor}

A study on the length-weight relationship (LWR) of this species is expected to support several applications such as estimation of stock size and its harvesting. The variation of weight does not follow the cubic law since fishes do not retain the same physiology throughout their lifespan (Le Cren 1951 in Le Galliard et al. . 2005). The LWR in the present study indicates the isometric growth of both males $\left(\mathrm{W}=0.0076 \mathrm{~L}^{3.1296}\right)$ and female $\left(\mathrm{W}=0.0066 \mathrm{~L}^{3.1681}\right)$ and combine sex $\left(\mathrm{W}=0.0069 \mathrm{~L}^{3.1543}\right)$ with $\mathrm{b}>3$, and this illustrates the length increment proportional to its body weight (Figure 3). The examined specimens exhibited fork length and weight varying between 16.0-35.4 cmFL (Mean $=23.6 \pm 3.53)$ and 40-570 g $($ Mean $=221.6 \pm 85.4)$. It should be noted that LWR parameters were considered as mean annual values for this torpedo scad species since the data was collected over this period.

Table 1. Criteria of ovary development stages

\begin{tabular}{llll}
\hline Stage & Description & Ovary & Eggs \\
\hline I & Resting & Undeveloped, small, translucent & Nonvisible to naked eye \\
II & Developing & Opaque & orange color visible and opaque \\
III & Ripe & Fills body cavity & Translucent, large and round \\
IV & Spawning & Release eggs when pressed & Large, translucent, some free ovary \\
V & Spent & Shrinking/slack & Some residual eggs \\
\hline
\end{tabular}



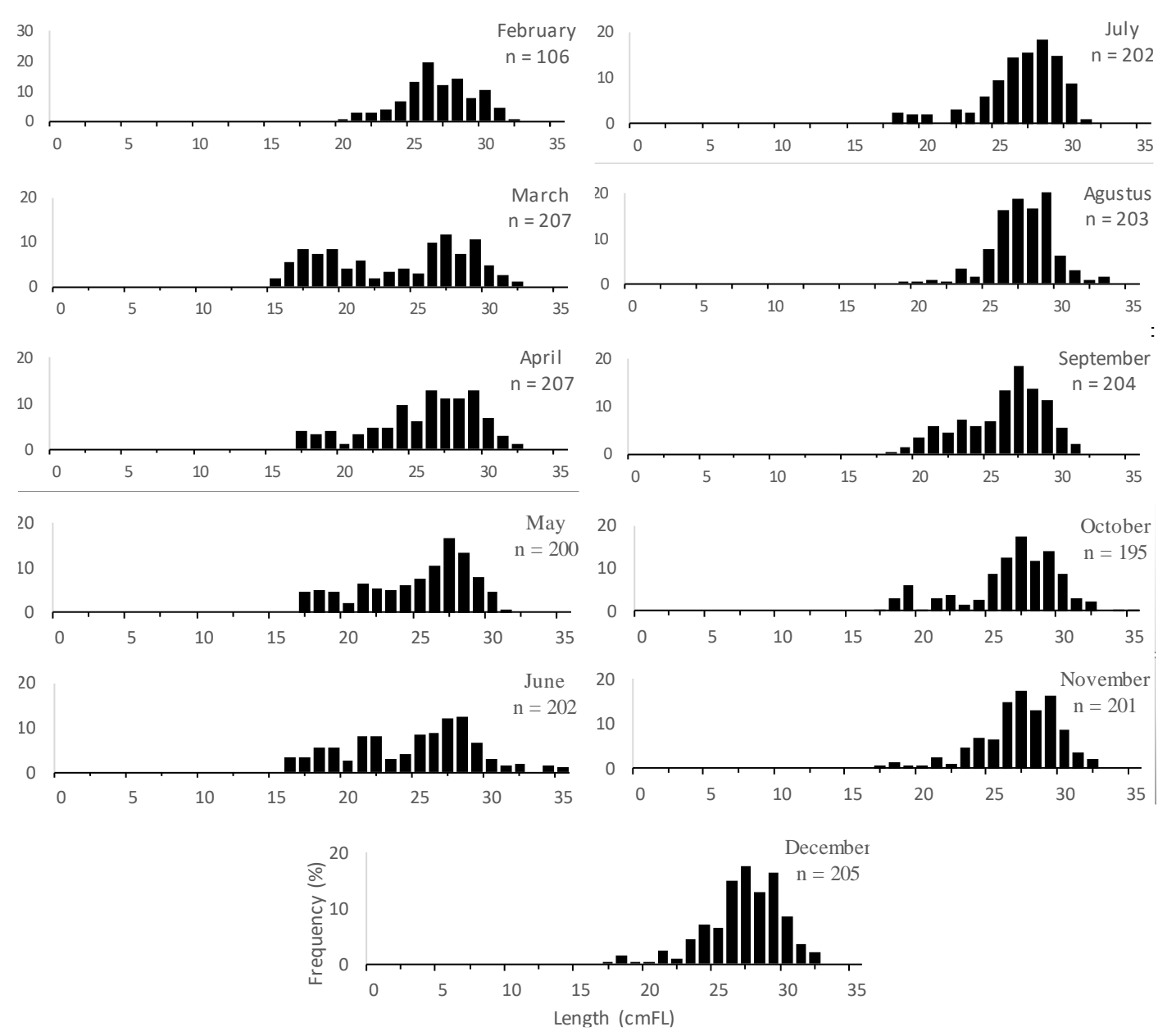

Figure 2. Monthly length-frequency distribution of Megalaspis cordyla (February-December 2017)

This value suggested that this species have a relatively fast growth rate and tend to be fat. To verify if $b$ for each group of sex is statistically significantly different from the prediction assigned for isometric growth $(b=3)$, student ttest comparison was performed. The result indicates that growth pattern showed that LWR of male $(\mathrm{p}=4.8 . \mathrm{E}-252)$, female $(p=5 . E-252)$ and combined $(p=1 . E-219)$ were insignificantly different $(p<0.05)$. The coefficient of determination $\mathrm{r}^{2}$ values varied between 0.964-0.973. This high coefficient of determination values obtained in the analysis means a good quality of the prediction of a power regression.

Another similar study in India, Bangladesh, and Malaysian waters indicated that LWR showed that growth parameters (b) of male and female Megalaspis cordyla are different within and among waters in coastal waters of south Asian (Table 2). The isometric coefficient estimated in the present study (3.1256-3.1681) was higher than other regional and international findings on the biometric of fish studied. Nevertheless, the estimated coefficient is within the expected range of 2.5-4.0 that commonly observed in Teleostei (Hile 1936; Martin 1949 in Le Cren 1951).

The sex ratio provides the basic information needed to assess the potential reproduction and stock size estimation (Vicentini and Araujo 2003). The chi-square $\left(\chi^{2}\right)$ verified that the overall sex ratio of $\mathrm{M} / \mathrm{F}=1.07: 1$ is not significantly different $(p=0.026 ; p<0.05)$ between male and female groups of fish (Figure 4). This proportional ratio indicates that long term harvesting of this species by seiner fisheries still maintains theorized natural selection, which always to equal proportion as common features of the natural population (Fisher 1930 in Fryxell et al. . 2015). This equal proportion leads fishing pressure to this fish resource doesn't impact the demographic structure of this species.

The Fulton's condition factor of fish $\left(K_{n}\right)$ is the common parameter to represent the relative healthy index of fish within its habitat. A heavier fish in a given length representing a better physiological condition (Froese 2006). Naie et al. (2015) inform that relative condition factors could provide essential indicators of different life stages in a particular ecosystem to support fisheries management. Scattered diagram of length to Fulton condition factors by sex indicated that both sexes of the torpedo scads were in a healthy condition with an index of greater than 1 (Figure 5). The male index ranging from 0.93 to 1.29 with an average of $1.14 \pm 0.08$ while for female was broader, ranging from 0.86-1.64 and the average was relatively the same at $1.14 \pm 0.10$. A similar study was carried out in Karachi waters of Pakistan, the condition factors ranging from 0.5 to 1.192 (Ahmed et al. 2013). 
Table 2. Length-weight relationship $M$. cordyla compared to previous studies in other waters.

\begin{tabular}{|c|c|c|c|c|c|c|c|}
\hline \multirow{2}{*}{ Author (s) } & \multirow{2}{*}{ Areas } & \multicolumn{2}{|c|}{ Combine } & \multicolumn{2}{|c|}{ Female } & \multicolumn{2}{|c|}{ Male } \\
\hline & & $\mathbf{a}$ & $\mathbf{b}$ & $\mathbf{a}$ & $\mathbf{b}$ & & \\
\hline \multirow{3}{*}{ Reuben et al. 1992} & East coast India & 0.000012 & 2.94 & - & - & - & - \\
\hline & Northwest India & 0.000127 & 2.52 & - & - & - & - \\
\hline & Southwest India & 0.000050 & 2.72 & - & - & - & - \\
\hline Saker et al. 2004 & Mumbai coast India & 0.000010 & 2.88 & 0.00020 & 2.46 & 0.00007 & 2.64 \\
\hline Sivakami 1995 & Cochin India & 0.013419 & 2.69 & 0.00865 & 2.86 & 0.01741 & 2.58 \\
\hline Zafar et al. 2000 & Bangladesh & 0.017940 & 2.82 & - & - & - & - \\
\hline Panda et al. 2011 & Mumbai India & 0.008577 & 3.02 & 0.00713 & 3.08 & 0.01119 & 2.92 \\
\hline Dash et al. 2014 & Malaysia & 0.034000 & 2.64 & 0.02100 & 2.77 & 0.03400 & 2.65 \\
\hline Present study & Java Sea Indonesia & 0.007000 & 3.15 & 0.00660 & 3.17 & 0.00760 & 3.13 \\
\hline
\end{tabular}

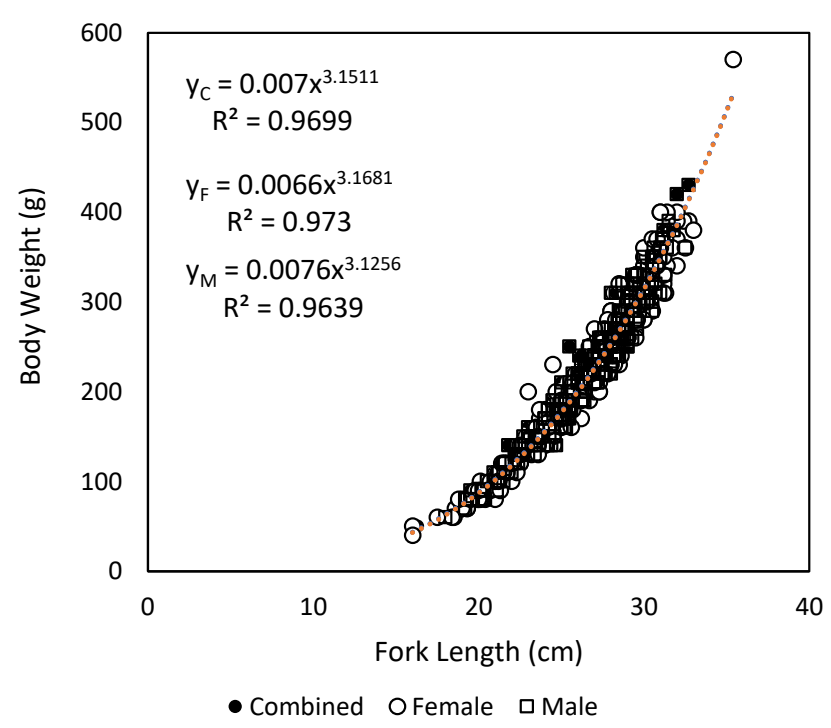

Figure 3. Length-weight relationship of Megalaspis cordyla by sex

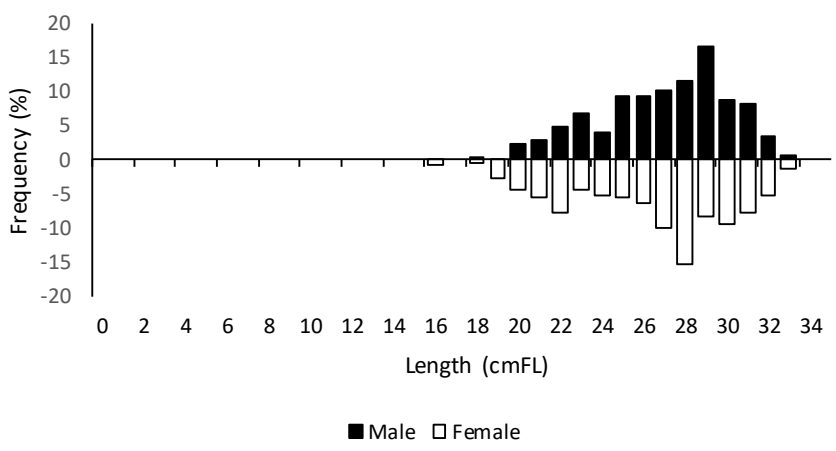

Figure 4. Distribution of length of torpedo scads by sex of Megalaspis cordyla

\section{Maturity, and gonadosomatic index}

Distribution of maturity stages by sex showed that $77 \%$ of all male specimens were at immature stages (I and II), $22 \%$ at ripe (III), and $<1 \%$ spawning specimens (IV). The monthly distribution of the maturity stage indicates that an

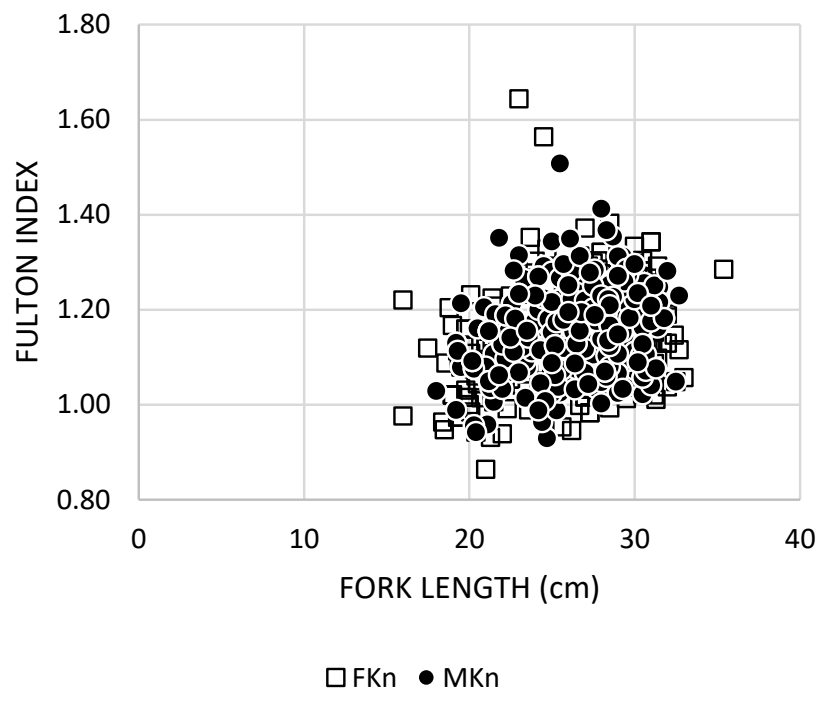

Figure 5. The scattered plot of Fulton's condition factor by sex of Megalaspis cordyla

immature stage occurred for each month except in November. The proportion of developing stages found for the entire period of observation with the highest $(90 \%)$ occurred in July while the lowest in April (33\%) (Figure 6 left). The ripe stage appears from April to July and September to December. The female specimens were also mostly at immature stages of resting and developing (I and II) $(63 \%), 35 \%$ ripe, and 2\% spawning (Figure 6 right). Ripe stage (III) occurs in each month of the year, with the highest proportion found in August (61\%) and July as the lowest (19\%). However, hardly any spawning specimens observed during this period except in November. Data are not sufficient to estimate the peak spawning season, and even the early maturing/ripe stage found during the year. Another thought suggested that the low percentage of spawners that occurred in November probably due to most of these mature cohorts distributed outside the fishing ground and untapped by this seiner fishery as described in the previous study of scads (Decapterus macrosoma) in the Java Sea (Sadhotomo 2006). 
Bodyweight of females ranged was from 40 to $570 \mathrm{~g}$ with a length of 16 to $35.4 \mathrm{~cm}$. The gonad weight ranged was from 0.02 to $36.33 \mathrm{~g}$, with an average of $6.61 \mathrm{~g}$ (Figure 7). This range of gonad weight indicates that most of the specimens $(74 \%)$ were at less than $10 \mathrm{~g}$. The linear regression of body weight to gonad weight showed that a wide range of gonad weight occurred at more massive than $260 \mathrm{~g}$ or equivalent to the length of approximately 27.0$29.5 \mathrm{~cm}$. The highest gonad weight occurred larger than $400 \mathrm{~g}$ in body weight or equal to $31.0 \mathrm{~cm}$ length. The average male gonad weight was $5.56 \pm 4.64 \mathrm{~g}$ and female at $6.69 \pm 6.16 \mathrm{~g}$ and ranging from 0.02 to $36.33 \mathrm{~g}$, which was heavier than the male gonad of 0.04 to $24.77 \mathrm{~g}$. It was found that the gonad weight of both sexes is insignificant with $p=0.010106$ ( $p<0.05)$. The body weight to gonad weights correlation showed that the determinant coefficient of female specimens is stronger $(0.73)$ than male specimens (0.58), and this probably due specimens of male gonad were mostly at immature stage.

A monthly gonadosomatic index (GSI) observed only for the female specimens. The result showed a broad range of GSI occurred each month (March to December) of female species. This wide variation was also found along the Ratnagiri coast of Maharashtra India (Jadav and Mohite 2014). The highest GSI found in April (7.2) and November (7.87) and the lowest value (0.04) in March. The average GSI ranged from 1.25 to 3.84 (Figure 8). Variability of GSI coincides with gonad weight and maturity stages relationship (Figure 9), which shows that each maturity stage has a broad range of gonad weight. The male GSI ranged from 0.05 to 6.35 with an average of $2.16 \pm 1.43$ while female specimens 0.04-8.05 with an average of 2.49 \pm 1.78 , however these average GSI by sex are significantly different $(\mathrm{p}=0.115>0.05)$. A similar study by Qamar and Panhwar (2018) indicated that the highest GSI of unsexed specimens of torpedo scads in the Northern Arabian Sea coast of Pakistan noted in January and May, whereas the lowest in November.
There are overlaps weight of gonad, particularly on maturity stage II and III of both sexes, and these deviations were probably related to the limited number of specimens during macroscopic observations. There still no clear information to confirm this overlaps. However, the same case was also found in the other small pelagic species of $R$. kanagurta, which translucent condition occurred in the relatively large size of a female with little weight of gonad (Oktaviani et al. 2014). A wide range of gonad weight in maturity stage III (ripe) could probably explain that this group of fish with gonad weight of $<10 \mathrm{~g}$ (arbitrary) belongs to the specimens in repeated spawning. This phenomenon drives the reproduction characteristic of torpedo scads as multi-spawner, which commonly found in small pelagic species in the tropics (Oktavian et al. 2015).

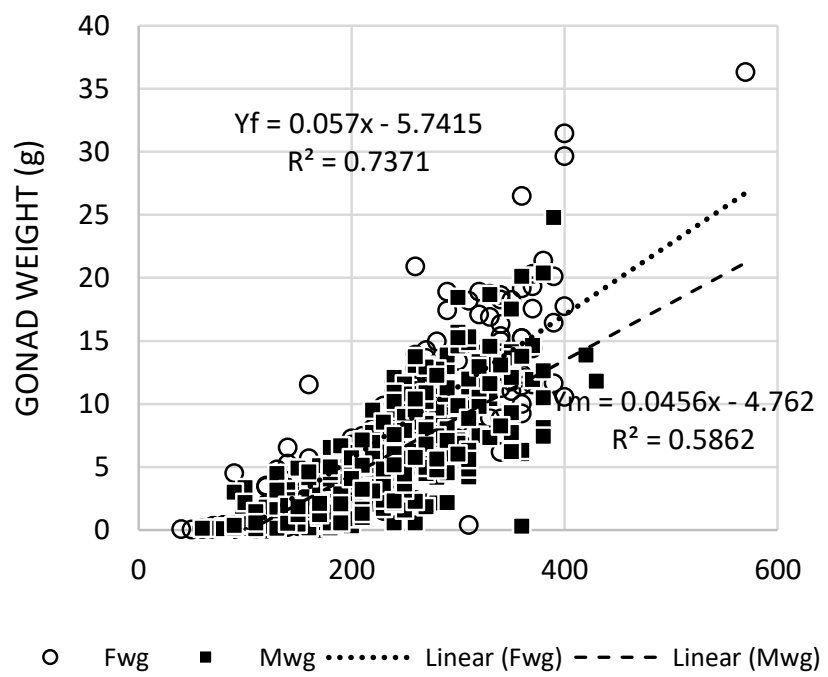

Figure 7. Body and gonad weight relationship of Megalaspis cordyla
M

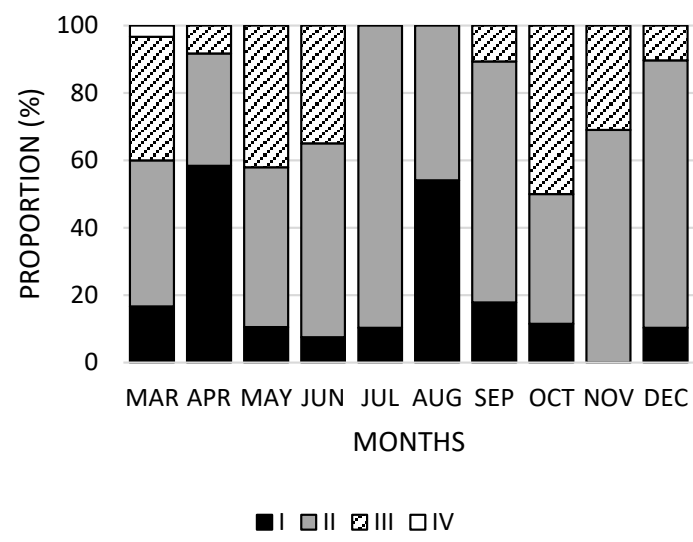

$\mathrm{F}$

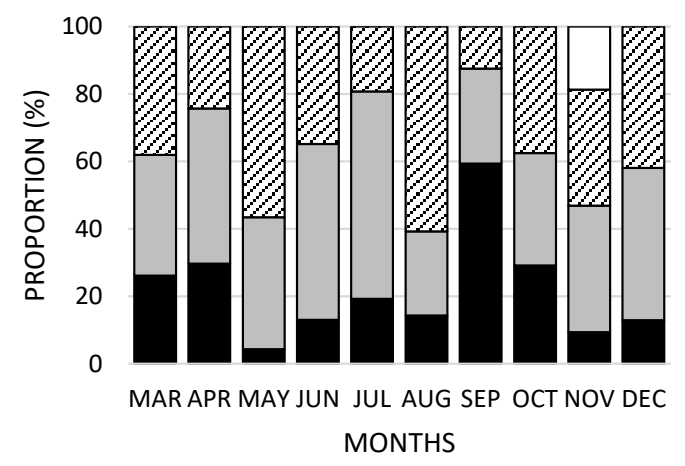

口

Figure 6. Proportions of monthly maturity stages of male (left) and female (right) of Megalaspis cordyla 
M

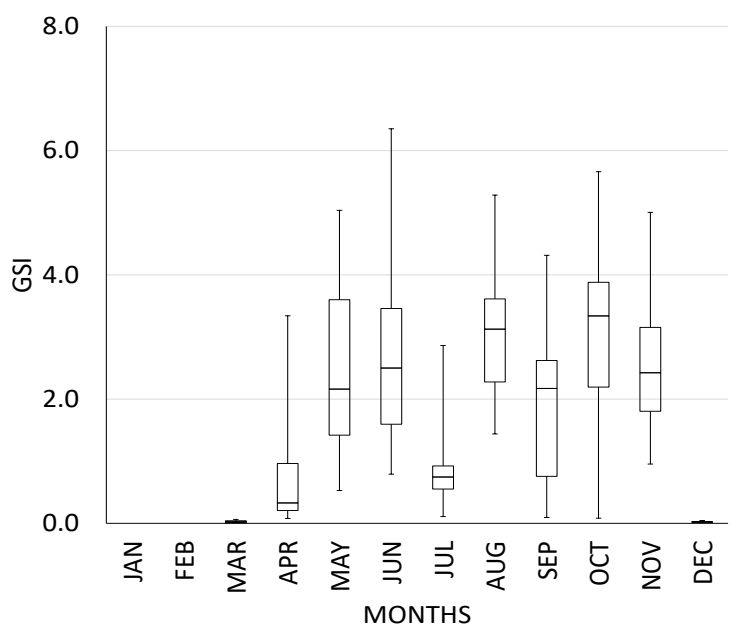

$\mathrm{F}$

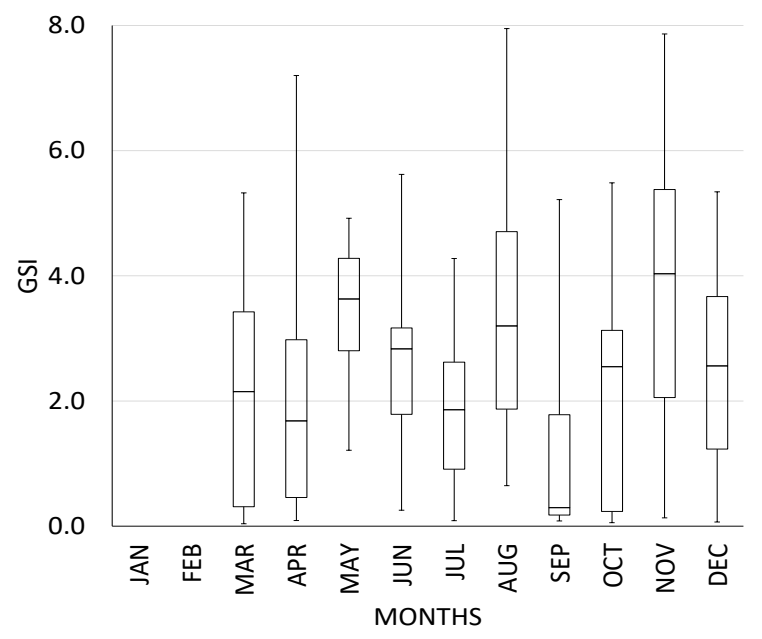

Figure 8. Distribution of male (left) and female (right) GSI by the month of Megalaspis cordyla

M

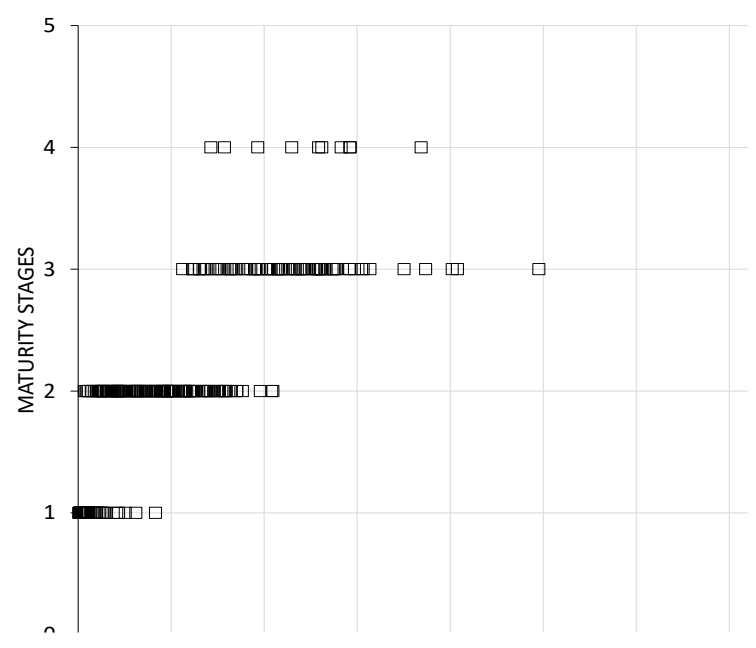

$\mathrm{F}$

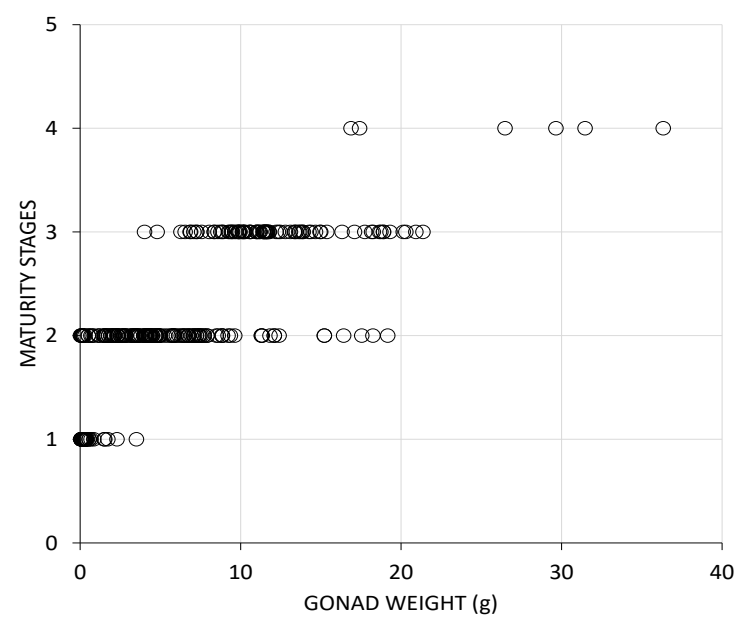

Figure 9. Scatter plot of female (left) and male (right) of gonad weight to maturity stages

This finding describes the role of GSI and maturity stages of Megalaspis cordyla indicate that the species spawn almost the whole year. However, the spawning sample available within a limited portion of the catch. Monitoring the performance of biological indicators and its harvesting data should be designed and implemented through regular observation. These would play a significant role in maintaining abundance at a sustainable level, species fitness, including keeping the ecosystem in a healthy condition. The previous study showed that high fishing pressures occurred in the Java Sea (Purwanto et al. 2014; Atmaja et al. 2017), particularly to the main species of Decapterus spp. The parameter found should be evaluated despite the high fishing pressures and fluctuation of environmental conditions that affect the early development phase (immature cohort) that dominated the size composition of the daily landing of small pelagic species. This lack of plasticity regarding biological sensitivity should be taken into account while developing the national biodiversity action plan.

\section{ACKNOWLEDGEMENTS}

We appreciate to anonymous reviewers for their comments to improve the quality of this manuscript. We are grateful to the Center for Fisheries Research and Research Institute for Marine Fisheries for their funding support. We also thank Rokhmat Waris as an enumerator and all Tegal, Central Java fishing port officers during observation in 2017. 


\section{REFERENCES}

Ahmed Q, Tabassum S, Yousof F, Turkmen M. 2013. Length-weight relationship and spatial distribution of Megalaspis cordyla (Linnaeus 1758) fish size frequency variation from Karachi Coast. Black Sea J Sci 3 (9): 115-123.

Anas P, Adrianto L, Muchsin I, Satria A. 2011. Analysis of the state of fisheries resource utilization as a basis for the management of sustainable capture fisheries in Cirebon marine waters. J Kebijak Perikan Ind 3 (2): 145-157. DOI: 10.15578/jkpi.3.2.2011.145-157.

Atmaja SB, Sadhotomo B, Nugroho D. 2017. Application of nonequilibrium surplus production model on scads (Decapterus macrosoma) fishery in the Java Sea. J Lit Perikan Ind 23 (1): 57-66.

Carpenter KE, Niem VH. 1999. The Living Marine Resources in the Western Central Pacific. Vo. 4. Bony fishes part 2 (Mugilidae to Carangidae). FAO, Rome.

CBD [Convention on Biological Diversity]. 2010. Target 6. Technical Rationale extended (COP/10/INF/12/Rev.1). https: //www.cbd.int/sp/targets/rationale/target-6

Das SK, De M, Ghaffar MA. 2014. Length-weight relationship and trophic level of hard-tail scad Megalaspis cordyla. Sci Asia 40: 317 322. DOI: 10.2306/scienceasia1513-1874.2014.40.317.

Flores A, Wiff R, Diaz E. 2014. Using the gonadosomatic index to estimate the maturity ogive: application to Chilean hake (Merluccius gayi gayi). ICES J Mar Sci 72 (2): 508-514. DOI: 10.1093/icesjms/fsu 155

Froese R. 2006. Cube law, condition factor, and weight-length relationships: history, meta-analysis, and recommendations. J App Ichthyol 22: 241-253.

Froese R. Pauly D. (eds.). 2019. FishBase.World Wide Web electronic publication.www.fishbase.org, version (08/2019).

Fryxell DC, Arnett HA, Apgar TM, Kinnison MT, Palkovacs EP. 2015 Sex ratio variation shapes the ecological effects of globally introduced freshwater fish. Proc Biol Sci 282 (1817): 20151970. DOI: $10.1098 / \mathrm{rspb} .2015 .1970$.

Jadhav TD, Mohite SA. 2014. Reproductive biology of Horse mackerel Megalaspis cordyla (Linnaeus, 1758) along the Ratnagiri coast of Maharashtra, India. J Mar Biol Ass India 55 (2): 35-40. DOI: 10.6024/jmbai.2013.55.2.01759-06.

King M, 2007. Fisheries Biology, Assessment, and Management. 2nd ed Blackwell, Oxford.

Le Cren ED. 1951. The Length-weight Relationship and Seasonal Cycle in Gonad Weight and Condition in the Perch (Perca fluviatilis). J Anim Ecol 20 (2); 201-219. DOI: 10.2307/1540.

Le Galliard GF, Fitze PS, Ferrière R, Clobert J. 2005. Sex ratio bias, male aggression, and population collapse in lizards. Proc Natl Acad Sci USA 13 (50): 18231-18236. DOI: 10.1073/pnas.0505172102.

Naie PG, Joseph S, Pilai VN. 2015. Length-weight relationship and relative condition factor of Stolephorus commersonii (Lacepede, 1803) exploited along the Kerala coast. J Mar Biol Ass India 57 (2): 27-31.

Nash RDM, Valencia AH, Geffen AJ. 2006. The origin of Fulton's condition factor. setting the record straight. Fisheries 31 (5): 236-238.
Nurdin E. 2007. The impact of light intensity to small scale seiners in Pemalang Central Java. Bawal 1 (6): 215-220. DOI: 10.15578/bawal.1.6.2007.215-220.

Oktaviani D, Matatar B, Nugroho D. 2015. The occurrence of translucent ovaries as indicator of peak spawning season of Indian Mackerel Rastrelliger kanagurta (Cuvier, 1816) in Mayalibit Bay Raja Ampat Islands. Bawal 7 (1): 51-57. DOI: 10.15578/bawal.7.1.2015.51-57

Oktaviani D, Supriatna J, Erdmann M, Abinawanto. 2014. Maturity stages of Indian mackerel Rastrelliger kanagurta (Cuvier, 1817) In Mayalibit Bay, Raja Ampat, West Papua. Intl J Aquac Sci 5 (1): 67 76.

Purwanto, Nugroho D, Suwarso. 2014. Potential production of the five dominant small pelagic fish species groups in the Java Sea. Ind Fish Res J 20 (2): 59-67. DOI: 10.15578/ifrj.20.2.2014.59-67.

Qamar N, Panhwa SK. 2018. Assessment of maturity, reproduction and reproductive potentials of torpedo scads, Megalaspis cordyla (Linnaeus, 1758) from Northern Arabian Sea Coast of Pakistan. Russian J Mar Biol 44 (1): 42-50.

Qamar N, Panhwar SK, Brouwer S. 2016. Population characteristics and biological reference point estimates for two carangid fishes, Megalaspiscordyla, and Scomberoides tol, in the Northern Arabian Sea Coast of Pakistan. Pakistan J Zool 48 (3): 869-874.

Razzaq S, Kalhoro MA, Memon AM, Buzdar MA, Shafi M, Saeed F, Baloch A. 2019. Fishery stock assessment of Megalaspis cordyla by using non-equilibrium surplus production models in the Arabian Sea Coast of Pakistan. J Anim Plant Sci 29 (1): 132-140.

Reuben S, Kasim HM, Sivakami S, Nair RPN, Kurup KN, Sivadas M, Noble A, Nair SKV, Raje SG. 1992. Fishery, biology, and stock assessment of carangid resources from the Indian seas. Indian J Fish 39: $195-234$.

Sadhotomo B. 2006. Population dynamics of the main pelagic species exploited in the Java Sea: Biological parameter estimates. Ind Fish Res J 12 (1): 37-63. DOI: 10.15578/ifrj.12.1.2006.37-63.

Sajina AM, Chakraborty SK, Jaiswar AK, Pazhayamadom DG. 2011. Stock structure analysis of Megalaspis cordyla (Linnaeus, 1758) along the Indian coast based on truss network analysis. Fish Res 108 (1): 100-105. DOI: 10.1016/j.fishres.2010.12.006

Saker Y, Jaiswar AK, Chakraborty SK, Swamy RP. 2004. Morphometry and length-weight relationship of Megalaspis cordyla (Linnaeus, 1758) from Mumbai coast. Indian J Fish 51: 481-486.

Sivakami S. 1995. Fishery and biology of the carangid fish Megalaspis cordyla (Linnaeus) off Cochin. J Mar Biol Assoc India 37: 237-48.

Stevenson RD, Woods WA. 2006. Condition indices for conservation: new uses for evolving tools. Integer Comp Biol 46 (6): 1169-1190. DOI: $10.1093 / \mathrm{icb} / \mathrm{icl} 052$.

Vicentini RN, Araújo FG. 2003. Sex ratio and size structure of Micropogonias furnieri (Desmarest, 1823) (Perciformes, Sciaenidae) in Sepetiba Bay, Rio de Janeiro, Brazil. Braz J Biol 63 (4): 55966.DOI: 10.1590/S1519-69842003000400003.

Widodo J, Burhanuddin. 1995. Systematics of the small pelagic fish species. In: Nurhakim, Potiers (eds.). Biology, Dynamics, and Exploitation of the Small Pelagic Fishes in the Java Sea. ORSTOMAARD, Jakarta.

Zafar M, Mustafa MG, dan Haque MA. 2000. Population Dynamics of Megalaspis Cordyla (Linnaeus 1758) From Northeastern Part of the Bay of Bengal, Bangladesh. Indian J Fish 47 (3): 163-168. 